\title{
Poverty and Shared Prosperity 2016: Taking on Inequality
}

THE WORLD BANK

Washington D.C., 2016, pp. 170

Book review by MARTINA PEZER*

doi: $10.3326 /$ pse.41.4.5

\section{* Received: July 7, 2017}

Accepted: September 7, 2017

\section{Martina Pezer, M.A.}

Institute of Public Finance, Smičiklasova 21, 10000 Zagreb, Croatia 
Global trends in inequality and their economic effects have become the subject of vigorous debate since the global financial crisis. The United Nations and the World Bank, which have focused on poverty alleviation since long before the crisis, have significantly strengthened their analytical and policy work on income and wealth inequality. One result of these efforts is the World Bank's inaugural flagship report Poverty and Shared Prosperity 2016: Taking on Inequality, which showcases the Bank's latest thinking and policy work on these issues. It emphasises the role of inequality-reduction in ending poverty, gives examples of successful approaches to reducing inequality and fighting poverty in different countries, and offers some guidelines on the design of policies to reduce inequality.

The report does not break new ground as did, for instance, Piketty's Capital in the $21^{\text {st }}$ century, in terms of paradigms or data, but offers a very useful summary of research, policy arguments and data sources on poverty and inequality issues. It is perhaps most useful for researchers and policymakers who are new to this field, and want to benefit from country experiences and research highlights. But it will also be welcomed by the interested public and civil society organisations, who will gain valuable knowledge on the subject due to the simple explanations, useful definitions and a good overview of the evolution of research and policy work on these issues. In sum, a reader will get a coherent picture of poverty and inequality around the world and a sense of how they might evolve under different scenarios in the future.

Poverty and Shared Prosperity 2016 consists of six chapters. The first sets the stage by explaining the goals of the World Bank and how their achievement is being assessed. It also dedicates a section to data availability, which varies greatly around the world.

The second chapter, "Global Poverty", presents the latest data and trends on global and regional poverty. The extreme poor are defined as those living on a daily income below USD 1.90 (in 2011 purchasing power parity). It gives a profile of the poor: most of them are young, living in rural areas in large households with numerous children, are uneducated, and work in agriculture. Sub-Saharan Africa has over half of the world's poor.

The third chapter deals with shared prosperity, a new concept of the World Bank measured as the income growth of the bottom $40 \%$ of the population. The goal of boosting shared prosperity can be achieved with larger average income growth rates for the bottom $40 \%$, which causes the most disadvantaged sectors to make quicker progress. The key message of the chapter is that achieving shared prosperity and at the same time reducing poverty is not easy to achieve in an environment of low and declining growth rates. A simulation of poverty rates in 2030 suggests that a significantly greater prosperity-sharing will be needed than seen so far in order to reduce the poverty rate to $3 \%$ of the world population from $10.7 \%$ in 2013. 
The fourth chapter, "Inequality", deals with inequality in incomes and consumption expenditure and its role in poverty reduction over long time horizons. The authors decompose changes in poverty into contributions of economic growth and those of changes in inequality. The conclusion of an extensive analysis is that global income inequality - i.e. the inequality among all citizens worldwide, as if the world's population lived in a single state entity - increased from the $1820 \mathrm{~s}$ through the 1980s. Since the early 1990s, and especially since 2008, there has been an exceptional period of falling global inequality, which can be explained almost entirely by the rapid growth of middle-class incomes in China and India relative to the stagnating incomes of the middle classes in advanced economies. Regionally, Latin America and the Caribbean, and more than half the African countries have very high levels of income inequality, with Gini indices exceeding 40. It is a pity that the analysis in this chapter does not extend to wealth inequality, to which reference is not made, even though data for a number of countries, such as the World Wealth and Income Database ${ }^{1}$ of the Paris School of Economics, are readily available and adduced in the report.

Particularly interesting for policymakers are five case studies analysed in the fifth chapter, "Reductions in Inequality: A Country Perspective". Brazil, Cambodia, Mali, Peru and Tanzania have successfully reduced poverty and inequality in recent years. The common feature of their experiences is that economic growth is the most important driver of reductions in inequality and poverty, and hence of improvements in shared prosperity. Almost half of the reduction in income inequality and poverty comes from improved employment opportunities, alignment of macroeconomic and fiscal policies with sound sector-specific interventions, and public investment. As the authors repeatedly state, there is no room for complacency as various internal (fiscal discipline, political conflicts) and external challenges (climate change) remain.

The final chapter, "Reductions in Inequality: A Policy Perspective", describes some general policy interventions that may usefully guide policymakers in their efforts to reduce inequality. These policies include early childhood development (breastfeeding and nutrition, parenting skills, preschool attendance), universal healthcare, education for all, conditional cash transfers, investment in rural roads, electrification, and redistribution through taxation. The benefits of good healthcare, early childhood development, and quality schooling - not just increased enrolment - are long-term. They consist of improved well-being of the poorest, which enhances human capital accumulation in the society and raises expected lifetime earnings of the poor, thereby lowering income gaps. Conditional cash transfers and redistribution through taxation can have a strong short-term impact on inequality, but should be well targeted, constantly monitored, evaluated and adjusted.

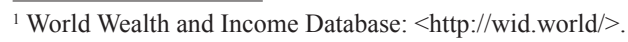


Compared with some other World Bank studies dealing with the same topic, this report is more accessible and hence intended for the general public and policymakers rather than, for instance, the two-volume collection of academic papers Inequality and Growth: Patterns and Policy. It also compares favourably with the World Bank's World Development Indicators 2017, which is more comprehensive in terms of the data but offers much less information on inequality and poverty issues. The report has an accompanying website ${ }^{2}$ with access to data sources and a short version of the report.

Taking on inequality is an evidence-based, easy-to-read report that fulfils expectations. While it focuses more on developing countries, not only in chapter 5 but also when describing approaches to dealing with income inequality and poverty, this is understandable in view of the scale of the challenge of poverty in regions such as Africa and Latin America. Researchers interested in these issues in higher-income countries will benefit slightly less, but should nevertheless find the report useful.

${ }^{2}$ Poverty and Shared Prosperity publication website: $<$ http://www.worldbank.org/en/publication/povertyand-shared-prosperity>. 


\section{REFERENCES}

1. Basu, K. and Stiglitz, J., 2016. Inequality and Growth: Patterns and Policy, Volume 1. Concepts and Analysis. World Bank: Palgrave Macmillan. Available at: <https://openknowledge.worldbank.org/bitstream/handle/10986/24983/ WB-IEA-v1.pdf? sequence $=1$ \&isAllowed $=\mathrm{y}>$.

2. World Bank, 2016. Poverty and Shared Prosperity 2016: Taking on Inequality. Washington D.C.: World Bank. Available at: <https:/openknowledge. worldbank.org/bitstream/handle/10986/25078/9781464809583.pdf>.

3. World Bank. 2017. World Development Indicators 2017. Washington, D.C.: World Bank. Available at: <https://openknowledge.worldbank.org/handle/ 10986/26447>. 